\title{
Regional Integration in South Asia: An Analysis of Trade Flows Using the Gravity Model
}

\author{
NASEEM AKHTER and EJAZ GHANI
}

\begin{abstract}
The study deals with trade benefits from the free trade agreement of the SAARC countries. It assesses the trade potential and trade creation with member and non-member countries. The gravity model has been used to measure the bilateral trade flows and to assess the trade effect for member and non-member countries.

Two analyses estimate the gravity model. The first analysis is based on cross-sectional data to capture the trade effect individually each year; and the second analysis utilises the pooled data to measure the overall trade effects and trade flows for the period 2003 to 2008 . The results from the two approaches show that estimated coefficients are consistent with the model assumptions. Both analyses show that the regional trade agreement of the SAARC countries could divert the trade for member countries as well as for the non-member countries. However, trade volume will increase only if the major partners (Pakistan, India, and Sri Lanka) sign regional trade agreements.
\end{abstract}

JEL classification: $\mathrm{F} 15$

Keywords: Trade; Regional Integration; Gravity Model

\section{INTRODUCTION}

The role of free trade agreements and regional integration has become an important feature in economic development. Many countries have moved to regional integration to foster their economic development and improve the standard of living of the people through opening up their economies. The NAFTA, the EU, and the ASEAN are examples of successful regional integration. The significance of regional integration has pushed the SAARC (South Asian Association for Regional Cooperation) countries to sign a free trade agreement.

The South Asia Free Trade Agreement (SAFTA) was signed by the seven member countries of the SAARC at Islamabad (Pakistan) on 6th January 2004, and it was implemented on 6th July 2006. According to the agreement, in the first phase, India, Pakistan and Sri Lanka have reduced their custom tariffs to 20 percent since the 1 st January 2008 and Bangladesh, Bhutan, Maldives and Nepal have reduced their custom tariffs to 30 percent. In the second phase, all countries will reduce the custom tariffs from 0 to 5 percent within the five years from 2008 to 2013. The first phase has been completed and countries have liberalised their trade within the region at a small degree.

The establishment of the SAFTA obviously creates important challenges as well as opportunities for the South Asian countries. This could have a significant impact on the domestic market, domestic producers, tariff revenues, welfare of the member countries, and

Naseem Akhter <naseemakhter_pide@yahoo.com> is Staff Economist and Ejaz Ghani <ejaz@ pide.org.pk > is Chief of Research, Pakistan Institute of Development Economics, Islamabad. 
the level of the regional trade. Therefore there is a need to examine the benefits and trade potentials which are associated with the free trade agreement of South Asian countries.

Indeed the main purpose of the study is to analyse the SAFTA in terms of trade potential and benefits for the member countries. Therefore, study emphasises the assessment of benefits from SAFTA in terms of increase in potential trade, increase in trade volume, increase in trade competitiveness, and trade creation with the member and non-member countries. Specifically the study addresses the following questions: Would the free trade agreement lead to economic gains? And would the integration of SAARC region move the countries toward the trade creation or trade diversion with the member countries and non-member countries?

The study uses gravity model to measure the bilateral trade flows and trade potential between the SAARC countries. With the most recent data; 2003 to 2008, it conducted cross section and pooled analysis to capture the performance individually each year. The limitation of the study is that it is based on data which is collected in South Asian Preferential Trade Agreement (SAPTA) period. Therefore the study has measured the trade potential for SAFTA countries by using the SAPTA performance.

The findings of the study suggest that member countries have less potential for trade if all the countries of the region are taken together in which case there would be some trade diversion within the region. In this context, the reduction of tariff may not affect the level of trade significantly. Also, the study shows that the signing of SAFTA would also divert the trade from other countries. However, in a hypothetical analysis, the study has found that SAFTA would be beneficial only if Pakistan, India and Sri Lanka enter into regional trade agreements. In this case reduction in the tariff level will not only increase the trade level between these countries but also with the non member countries.

This paper consists of five sections. Section 2 provides literature review. Section 3 depicts an overview of regional trade integration in South Asia. Section 4 describes the gravity model and the data sources. Section 5 present empirical results of the gravity model, while Section 6 highlights the conclusions.

\section{LITERATURE REVIEW}

Indeed the focus of our study is to measure the trade flows between the South Asian countries by employing gravity model. The gravity model is one of the successful stories in theoretical and empirical literature. Tinbergen (1962) in his prestigious work "Shaping the World Economy: Suggestions for an International Economic Policy", proposed this model and suggested that the bilateral trade flows between countries will be directly proportional to the Gross National Product and inversely proportional to the distance between them. Tinbergen's preliminary analysis lacked the theoretical foundation for the proposed model but the studies of Linnemann (1966), Prewo (1978), Anderson (1979), Bergstrand (1985), Anderson and Wincoop (2003) and others justified the gravity model on theoretical foundations.

Linnemann (1966) explained the gravity model as a reduce form of partial equilibrium of export supply and import demand. Anderson (1979) argued for differentiated goods by origin and used expenditure system by taking the share of total traceable goods expenditure as a function of transaction cost variables. The model developed in Bergstrand $(1985,1989,1990)$ extended the gravity model to address the issue of monopolistic competition with differentiated goods by country of origin. 
The study of Frankel (1999) focused on the relationship of international trade and living standard. It investigated that income and trade are correlated therefore it is difficult to identify the effect of trade on living standard. The study employed the geographic factors to address this problem. It is proposed that the variation in trade which is due to geographic factors can serve as a natural experiment for identifying the effects of trade because geographic factors are not a consequence of income or government policy, and there is no likely channel through which they affect income.

Anderson and Wincoop (2004) highlighted the importance of trade cost within the framework of gravity model and find significance of the trade cost and trade flows. Helpman, et al. (2006) further extended the gravity equation by incorporating the heterogeneity of the firms, zero-trade observations, asymmetric trade flows and the extensive margin of trade.

The gravity model has been used extensively in empirical literature. Some studies have used the gravity to analyse the impact of preferential free trade arrangements. Akram (2004) employed the gravity model to estimate the export potential with 154 countries including the SAARC countries for the major 19 sectors of the Pakistan economy. Using the cross sectional data the results of study indicated a higher magnitude of export potential with partner countries.

Rahman (2004) applied a generalised gravity model to analyse Bangladesh trade flows with its SAARC trading partners using the panel data estimation techniques. They estimated the gravity model of trade and showed that trade of Bangladesh is positively determined by the size of the economies, per capita GNP differential of the countries involved and openness of the trading countries.

The study of Bhatachariya (2004) estimated the bilateral trade flows of the India and Bangladesh using the gravity model in different tariff reduction scenarios and obtained the simulated results. These results added evidence that India's exports would increase more than its imports from Bangladesh. Further Reihan and Razzaque (2007) measured the trade creation and trade diversion and welfare effects for different regional integration and bilateral FTAs in South Asia with GTAP analysis. The findings of the study suggest that the free trade arrangement will lead to welfare gain for India, Sri Lanka and rest of South Asian countries except Bangladesh.

Although many studies have been conducted to analyse the trade pattern of the SAARC countries, many of them employed the gravity model but only focus on intraregional trade of India and Bangladesh in free trade agreement arrangement. This study would add to the literature by providing an assessment of trade potential, trade creation and trade diversion effects under the arrangement of SAFTA.

\section{REGIONAL TRADE INTEGRATION IN SOUTH ASIA}

\subsection{Regional Trade Performance ${ }^{1}$}

South Asian intraregional trade volume is very low relative to other regions of the world. According to some estimates, it is currently around \$5-6 billion per year. ${ }^{2}$ India is big player in this region therefore it has dominated regional trade. Its exports have increased more

${ }^{1}$ See Appendix: overview of the macroeconomic indicator of the SAARC countries.

${ }^{2}$ COMTRADE. 
than threefold during 1996 to 2008. In contrast, its imports from the South Asian countries remain low. According to IMF trade statistics, India's export share in intraregional trade was 4.42 percent and the import share was only 1.2 percent in the year 2008 .

Table 1

Intraregional Trade Shares

\begin{tabular}{|c|c|c|c|c|c|c|c|c|c|c|c|c|}
\hline \multirow[b]{2}{*}{ Countries } & \multicolumn{6}{|c|}{ Exports } & \multicolumn{6}{|c|}{ Imports } \\
\hline & 1990 & 1995 & 1998 & 2004 & 2006 & 2008 & 1990 & 1995 & 1998 & 2004 & 2006 & 2008 \\
\hline India & 2.7 & 5.1 & 5.6 & 5.5 & 6.95 & 4.42 & 0.4 & 0.6 & 1.1 & 0.8 & 1.15 & 1.2 \\
\hline Pakistan & 4 & 3.2 & 4.9 & 3.7 & 4.15 & 4.48 & 1.6 & 1.5 & 2.4 & 3.1 & 3.5 & 6.80 \\
\hline Bangladesh & 3.1 & 2.3 & 2.7 & 1.6 & 1.4 & 2.13 & 7 & 17.7 & 17.5 & 16.2 & 21.45 & 17.6 \\
\hline Sri Lanka & 3.7 & 2.7 & 2.4 & 8.6 & 7.95 & 7.65 & 7 & 11.4 & 12.9 & 19.7 & 25.65 & 29.68 \\
\hline Nepal & 7.7 & 9.2 & 36.2 & 53.3 & 67.55 & - & 13.4 & 17.5 & 31.7 & 42.6 & 51.75 & - \\
\hline Maldives & 13.8 & 22.5 & 16.6 & 16.4 & 17.8 & 16.40 & 7.4 & 4.5 & 7.7 & 16.3 & 16.45 & 19.67 \\
\hline Bhutan & 9.6 & 87.9 & 81.9 & 80.5 & - & - & 10.9 & 57.5 & 59.9 & 60.5 & 85 & - \\
\hline South Asia & 3.1 & 4.3 & 7.3 & 5.5 & 5.6 & 5.7 & 2 & 3.8 & 4.3 & 4.1 & 5.25 & 4.05 \\
\hline
\end{tabular}

Bangladesh was the second largest contributor to trade within South Asia, both in terms of actual trade volume and as a percentage of overall intraregional trade. It was surpassed by Sri Lanka since 2002 as the second largest intraregional trader. The annual contribution of Bangladesh in exports ranges between 2 to 3 percent. The imports share of Bangladesh increased remarkably from 7 to 22 percent during the period 1990 to 2008 . Pakistan's economy is the region's second largest, but its annual contributions to intraregional trade have been moderately increased between 1998 and 2008.

Although the South Asian countries are moving toward open economies, the intraregional trade in South Asia is very small. It was approximately 2.4 percent in 1990 of total SAARC trade. It has increased only to 4.3 and 4.1 percent by the year 2001 and 2008 respectively (see Figure 1). The trend of trade share show that the percentage trade shares of South Asian countries ranged between 3 and 5 percent. The low level of intraregional trade in SAARC countries is due to slow industrialisation process and identical comparative advantages.

Fig. 1. SAARC Intra-regional Overall Trade

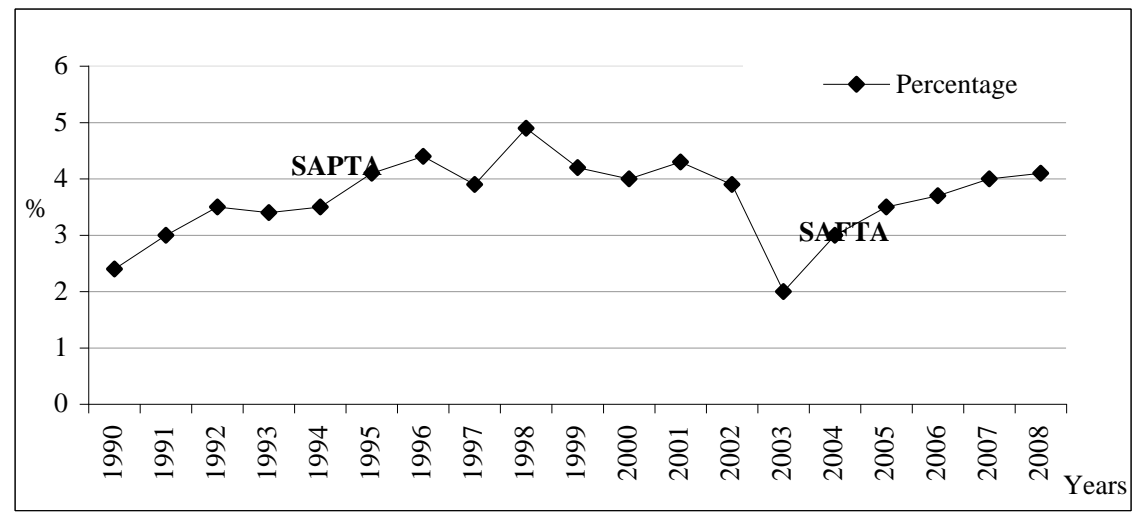

Source: IMF Direction of Trade Statistics. 


\subsection{Tariff Reduction under Agreement}

The South Asian free trade agreement envisages trade and economic cooperation among Bangladesh, Bhutan, India, Maldives, Nepal, Pakistan and Sri Lanka. In the first phase, Pakistan, India and Sri Lanka are required to reduce their tariff rates to 20 percent within two years. Bhutan, Bangladesh, Maldives and Nepal are required to reduce their tariff rates to 30 percent from the existing tariff rates by the year 2008. Therefore, member countries are liberalising their trade with the proposed tariff reduction rates especially for the South Asian region.

In the second phase, the Pakistan and India would reduce their tariff rates from 0 to 5 percent by the year 2013 and Sri Lanka would reduce these by the year 2014. The other countries would reduce tariff rates from $0-5$ percent by the year 2015 . Table 2 provides summary of tariff reduction schedule under SAFTA. By January 2015, the SAFTA will be fully implemented and the tariff rates would reduce to zero for all goods except the country's sensitive products.

It is important to point out here that regional economic integration in South Asia holds significance from the perspective of South-South Trade. Recent decades have witnessed an increasing volume of trade among developing countries mainly as a result of free trade agreements. These economies are increasingly engaged in international production systems thus raising the volume of trade among LDCs. All the South Asian economies are developing countries and in this context regional trade agreement will provide an important framework to enhance intra-regional trade.

Regional economic integration in South Asia should also be seen as an important initiative in the context of the recent financial crisis which has adversely affected the trade volumes of the South Asian countries. As demand in the developed market economies has contracted, the exports of the South Asian economies have also witnessed a decline mainly because the developed economies remain the major markets for South Asian exports. In this scenario, regional economic integration in South Asia can provide important benefits in terms of provision of market access to the regional countries. This will help diversify export markets and enhance regional exports.

Table 2

Tariff Rate Reduction under SAFTA

\begin{tabular}{|c|c|c|c|c|}
\hline \multirow[b]{2}{*}{ Existing Tariff Rate } & \multicolumn{2}{|c|}{ Bangladesh, Bhutan, Maldives, Nepal } & \multicolumn{2}{|c|}{ India, Pakistan, Sri Lanka } \\
\hline & $\begin{array}{c}\text { Proposed } \\
\text { Reduction under } \\
\text { SAFTA }\end{array}$ & Timeline & $\begin{array}{c}\text { Proposed } \\
\text { Reduction under } \\
\text { SAFTA }\end{array}$ & $\overline{\text { Timeline }}$ \\
\hline First Phase & & & & \\
\hline $\begin{array}{l}>20 \% \\
<20 \%\end{array}$ & - & & Reduce to $20 \%$ & 2 Year \\
\hline$>30 \%$ & Reduce to $30 \%$ & 2 Year & $\begin{array}{c}\text { Annual } \\
\text { Reduction }\end{array}$ & 2 Year \\
\hline$<30 \%$ & $\begin{array}{c}\text { Annual } \\
\text { Reduction }\end{array}$ & 2 Year & & \\
\hline $\begin{array}{l}\text { Second Phase } \\
\leq 20 \% \\
\leq 30 \%\end{array}$ & Reduce $0-5 \%$ & 3 to 5 Year & Reduce to $0-5 \%$ & 2 Year \\
\hline
\end{tabular}




\section{METHODOLOGY AND DATA}

\subsection{Gravity Model}

The gravity model is a widely used tool to estimate the bilateral flows between member countries. Its concept is based on Newton's law of gravity and was firstly used by Tinbergen (1962). It relates the bilateral trade flows to GDP, distance, border and other factors that affect the trade patterns. The standard gravity model postulates that the trade between member countries is proportional to the national income and inversely related to the distance which is a proxy for transportation cost and information cost because these costs are reduced as geographical distances decrease. Other variables such as country size, common border, common language, population size, infrastructure etc. are also included in the gravity model. The standard gravity model does not provide the theoretical foundations, however it has improved over the time.

The studies of Bergstrand (1990), Frankel (1999), Anderson and Wincoop (2003) and Helpman (2006) provide theoretical foundation for this model. Our study uses the extended form of the gravity model that includes some important variables such as trade cost which is represented by bilateral tariffs. The inclusion of the trade cost variable explains the bilateral trade flows more accurately.

In empirical literature, studies have added dummy variables for participation in various preferential arrangements. A positive coefficient of dummy variable for preferential arrangement indicates that both participants of the preferential arrangement would trade more with each other. This is called trade creation effect of regional arrangement. On the other hand, a negative coefficient shows that the members have loss in their trade because they are moving from low cost sources to the high cost sources. This is due to trade diversion effect. Some member countries are found to have trade creation within the preferential arrangement region but divert their trade with the non member countries.

The gravity model of trade equation in this study is given below, it is in log form. The log transformation adds the extra benefit that the resulting coefficient can be interpreted as elasticities

$$
\begin{aligned}
& \log \left(\operatorname{Trade}_{i j t}\right)=\alpha_{0}+\alpha_{1} \log \left(G D P_{i t} * G D P_{j t}\right)+\alpha_{2} \log \left(\text { PCGNP }_{i t} * P C G N P_{j t}\right)+\alpha_{3} \log \left({\text { Dis } \left.\tan c e_{i j}\right)}_{1}\right. \\
& \alpha_{4}\left(\text { Border }_{i j}\right)+\alpha_{5}(\text { tariffij })+\alpha 6(\text { SAFTA })+\alpha 7(\text { non }-S A F T A)
\end{aligned}
$$

From the estimated equation, Tradeijt is bilateral trade between countries $i$ and $j$ at the time $t$ (measured in million U.S. dollars), GDP is real gross domestic product of country $i$ and $j$ ), PCGNP is per capita income, Distance is the land distance in kilometers between two countries, and border is dummy variable that takes a value of 1 if two countries have common border and 0 otherwise. Tariff is trade cost borne by the partner $i$ and $j$. Hence the coefficient a1, a2, a4 will be positive and a 3 and a5 will be negative.

The expected sign of the GDP is positive. It shows that the bigger economies would trade more as compared to poor and less developed countries. It is also expected that trade would decrease with the increase in distance between partners. The increase in distance will raise the transport and information cost that would cause a reduction in trade among the partner countries. The expected sign of the border and per capita income is also positive but the expected sign of trade cost (tariff) will be negative. The higher trade cost would make the goods expensive and ultimately reduce the trade level. 


\subsubsection{Econometric Approach}

Since the study applies the cross section and pooled estimation approaches, therefore, the occurrence of heteroscadicity, multicollinearity and autocorrelation is possible. Problem of multicollinearity is possible if the correlation between two variables is very high. High multicollinearity increases variances of OLS estimator and lowers the significance levels of estimates. This can increase the chance of type II error. In our dataset, the pairwise correlation between two variables varies from -0.007 to 0.60 which is not very high. Gujrati (1988) and Judge, et al. (1988) consider 0.8 to be the critical threshold for serious problem of multicollinearity. According to Blanchard (1967) multicollinearity is essentially a data deficiency problem and sometimes we have no choice over the data that are available for empirical analysis. ${ }^{3}$

In OLS results, we found that the Durbin-Watson statistics are less than 2, indicating existence of autocorrelated errors in the sample. Most of our estimations are cross sectional therefore the low value of Durbin-Watson is natural and will not bias the results. The heteroscadicity is the problem of cross sectional data and it will weaken the reliability of the results therefore we have used the Generalised Least Sqaure (GLS) method, also known as FGLS in the literature, to estimate the gravity model for the South Asian countries. This technique is preferred over other techniques because of its superiority in dealing with the problems of heteroscadicity and autocorrelation. In our estimations we have used White Heteroscedasticity Test to minimise heteroscedasticity.

\subsubsection{Data}

The study makes use of the world development indicators for data on GDP, and per capita income for the specified countries. The data on Distance and border are collected from the website of CEPII and the data on bilateral trade flows have been collected from the IMF direction of trade. The bilateral tariff rates are collected from TRAINS (UNCTAD database) by using the WITS software which is developed by the UNCTAD and WTO. One limitation of the bilateral trade flows data is that it has zero trade values for some countries. The study has overcome this problem by including trade value between 1 and 2 in cases of zero trade. This technique removes the gap in the data and makes it estimable.

\section{RESULTS}

The gravity model equation is estimated by using cross sectional and pooled data. The use of cross section data gives us empirical evidence of the regional bilateral trade flows over the time. It uses yearly data from 2003 to 2008. The estimation with pooled data would measure the yearly effect of all variables on bilateral flows. The generalised least square technique is used to estimate the model. The advantage of generalised least square is that it is corrected for heteroscedasticity and autocorrelation.

The study has included twenty eight countries which are regular and significant trade partners of the South Asian countries. In this sample, most of the countries are member of regional trade agreements. For example, the regional agreements of ASEAN, European Union and NAFTA. Therefore, we have included four regional blocks to

${ }^{3}$ Blanchard, O. J., Comment, Journal of Business and Economic Statistics, Vol. 5, 1967, pp. 449-451. 
determine the effect of regional integration on trade. The composition of blocks is as follow; SAFTA1, it includes only Pakistan, India and Sri Lanka, SAFTA consists of all countries excluding Bhutan. ASEAN1 consists of Indonesia, Malaysia, Philippines, Singapore, Korea, Hong Kong, Thailand, except China whereas ASEAN2 has included regional members of the ASEAN countries. The NAFTA consists of US, Canada and Mexico. The EU includes Germany, Italy, UK, Netherlands, Spain, Belgium, France and Denmark.

The estimation of the gravity model with cross section data will provide us the variation in the trade potential over the year. We can compare the results of recent year with the previous years. GLS cross section results for the year 2007 and 2008 are presented in the Table $3 .{ }^{4}$

The study has made two types of estimation for the cross sectional analysis of the period 2003 to 2008. The first estimation includes all regional trading blocks and the second estimation includes only the SAFTA (see Table 3). The rationale behind these estimations is that it could differentiate the ultimate impact of SAFTA in the presence of other regional agreements and in the absence of the other regional block. This exercise can also shed light on the robustness of the analysis in terms of whether or not the impact of SAFTA remains the same or changes when other important regional agreements are include. ${ }^{5}$

The empirical results for the year 2008 show that the standard gravity model variables are statistically significant and have the expected signs. The estimated coefficient of the log of the product of two countries GDPs and GDP per capita are 0.721 and 0.198 respectively. These results suggest that the trade will increase with the increase in the country size but less than proportionately. It provides evidence that the increase in population of a country has positive impact on the trade flows. Economy size which is represented by GDP would increase the trade flows by 19 percent between members. The distance holds negative sign and statistically significant. It shows that the increase in transportation and information cost will decrease the trade between partners. The one percent increase in distance would decrease the trade by 26 percent, and if the member countries share a common border, trade roughly would increase to 3.22 time $[\exp (1.178)=3.22]$ as much as from the existing level. Trade cost is another important determinant of bilateral trade flows. It is negatively associated with bilateral trade volume. It would decrease trade by 38 percent on the level.

The assessment of trade potential, trade creation and trade diversion is also provided in Table 3. It shows that the dummy variable of the regional trade agreement SAFTA has negative sign. The negative sign of the coefficient indicates that the member countries of SAFTA would divert their trade. They would make trade 89 percent $[\exp (-2.32)=0.10]$ less the level at which they are trading.

The SAFTA would also divert trade with the non members because SAFTA has negative coefficient for the non-member countries. It is noted that Hassan (2001) has given similar results for the year 1996.

${ }^{4}$ The cross sectional results for the year 2003 to 2006 are reported in Appendix 2.

${ }^{5}$ See Frankel, et al. (1993) and Helpman, et al. (2006). 
Table 3

Estimates of Gravity Model with GLS

(Cross Sectional Results for the Year 2007 and 2008)

\begin{tabular}{|c|c|c|c|c|c|c|c|c|}
\hline \multirow[b]{2}{*}{ Variables } & \multicolumn{4}{|c|}{2008} & \multicolumn{4}{|c|}{2007} \\
\hline & Coefficient & T-statistics & Coefficient & T-statistic & Coefficient & T-statistics & Coefficient & T-statistic \\
\hline Constant & 3.083 & 1.407 & 3.459 & 1.645 & 2.685 & 1.501 & $4.826 * *$ & 1.957 \\
\hline LOGGDP & $0.721 *$ & 11.778 & $0.729 *$ & 12.790 & $0.701 *$ & 12.198 & $0.711 *$ & 13.218 \\
\hline LOGPCI & $0.198 *$ & 3.447 & $0.233 *$ & 4.170 & $0.178 *$ & 3.664 & $0.214 *$ & 4.169 \\
\hline LOGDIST & $-0.261 * *$ & -1.967 & $-0.379 *$ & -3.497 & $-0.313 * * *$ & -2.521 & $-0.464 *$ & -4.524 \\
\hline LOGTARIFF & -0.385 & 1.40 & -0.413 & 1.444 & -0.411 & 1.501 & -0.262 & 1.541 \\
\hline BORDER & $1.178 *$ & 3.461 & $0.667 *$ & 3.376 & $1.517 * *$ & 2.645 & $0.769 *$ & 3.345 \\
\hline SAFTA1 & $3.428 *$ & 2.947 & $3.354^{*}$ & 2.803 & $2.825 *$ & 3.190 & $2.159 *$ & 2.998 \\
\hline SAFTA1N & $1.636^{*}$ & 4.590 & $1.598 *$ & 4.548 & $1.432 *$ & 4.547 & $1.552 *$ & 4.194 \\
\hline SAFTA & $-2.326^{* * *}$ & -2.363 & $-2.307^{*}$ & -2.382 & $-2.924 *$ & -2.975 & $-2.221 *$ & -2.414 \\
\hline SAFTAN & $-1.243^{*}$ & -3.982 & $-1.188^{*}$ & -3.909 & $-1.472 *$ & -4.251 & $-1.183^{*}$ & -3.689 \\
\hline ASEAN1 & $1.194 *$ & 2.708 & - & - & $1.011 *$ & 2.019 & - & - \\
\hline ASEAN2 & 0.995 & 1.584 & - & - & $0.968 *$ & 1.908 & - & - \\
\hline $\mathrm{ECO}$ & -0.285 & -0.766 & - & - & -0.249 & -0.978 & - & - \\
\hline NAFTA & 0.717 & 1.699 & - & - & 0.731 & 1.081 & - & - \\
\hline $\mathrm{EC}$ & 0.449 & 1.664 & - & - & 0.502 & 1.197 & - & - \\
\hline $\mathrm{R}^{2}$ & 0.806 & - & 0.798 & - & 0.79 & - & -0.79 & - \\
\hline D.W & 1.81 & - & 1.792 & - & 1.79 & - & -1.8 & - \\
\hline
\end{tabular}

In contrast, the SAFTA1 is a hypothetical bloc which include Pakistan, India and Sri Lanka. The results indicate that if Pakistan, India, and Sri Lanka jointly sign an agreement, the trade level would be about 30 times $^{6}$ higher than the existing level of trade between these three partners. The SAFTA1 has not only potential for trade with member countries but also for the non member countries. The better economic conditions and infrastructure in Pakistan, India, and Sri Lanka as compared to the rest of SAARC countries could be reason of positive trade between these countries.

Although the overall findings suggest that regional arrangement is less effective but the trade creation potential between SAFTA1 countries provides a justification that SAARC countries could increase trade if they improve their economic conditions and develop better infrastructure. The results in Table 3 also suggest that even when SAFTA is considered as a regional block the trade of the South Asian countries could not be diverting with the other regions like ASEAN1 and ASEAN2. The coefficients of ASEAN1 and ASEAN2 show that the trade of South Asian countries and South East Asian countries would be positive and significant in the future.

The regional integration of South Asian countries would divert their trade. It would increase trade flows only if some countries (Pakistan, India and Sri Lanka) sign agreements. Similar results prevail for SAFTA and SAFTA1 when other regional blocs are excluded. The results from the second regression by including only SAFTA and SAFTA1 are consistent with the first regression results. Therefore, SAARC members not only reduce trade among them but also reduce trade with nonmember countries and trade creation emerges only if Pakistan, India and Sri Lanka sign an agreement.

$$
\left.{ }^{6} \text { [i.e., } \exp (3.42) \simeq 30.57\right] \text {. }
$$


Table 4

Estimates of Gravity Model with Pooled Estimation

\begin{tabular}{|c|c|c|c|c|}
\hline Variables & Coefficient & T-statistics & Coefficient & T-statistics \\
\hline Constant & $2.315^{*}$ & 2.675 & $5.897^{*}$ & 3.453 \\
\hline LOGGDP & $0.692 *$ & 13.875 & $0.689 *$ & 14.649 \\
\hline LOGPCI & $0.294^{*}$ & 3.116 & $0.385 * *$ & 2.924 \\
\hline LOGDIST & $-1.035^{*}$ & -4.728 & $-1.134^{*}$ & -4.932 \\
\hline LOG(Tariff) & -0.299 & 1.323 & -0.314 & 1.412 \\
\hline BORDER & $0.634 *$ & 3.995 & $0.654 *$ & 3.859 \\
\hline SAFTA1 & $2.919 *$ & 4.541 & $2.898^{*}$ & 3.687 \\
\hline SAFTA1N & $1.236^{*}$ & 6.332 & $1.215^{*}$ & 6.618 \\
\hline SAFTA & $-2.346^{*}$ & -4.441 & $-2.856 *$ & -5.232 \\
\hline SAFTAN & $-1.794 *$ & -8.569 & $-1.829 *$ & -7.867 \\
\hline ASEAN1 & $1.231 *$ & 4.483 & - & - \\
\hline ASEAN2 & $0.889 * *$ & 2.204 & - & - \\
\hline $\mathrm{ECO}$ & -0.398 & -0.694 & - & - \\
\hline NAFTA & 0.277 & 0.769 & - & - \\
\hline $\mathrm{EC}$ & 0.376 & 1.434 & - & - \\
\hline $\mathrm{R}^{2}$ & 0.801 & - & 0.79 & - \\
\hline D.W & 2.110 & - & 2.01 & - \\
\hline
\end{tabular}

We have also estimated the gravity model with the pooled data. This step measures the multiyear effect of change in trade flows and provides the robustness of the analysis. It provides evidence that GDP, per capita income, distance, boarder and tariff have similar affect as in cross sectional analysis.

\section{CONCLUSION}

The study has used gravity model to assess the trade potential and trade benefits for the South Asian countries. The analysis indicates the potential for trade creation exists provided that Pakistan, India, and Sri Lanka sign regional trade agreement. The cross sectional analysis for each year gives almost similar results. The empirical results show that the integration of the South Asian countries has little potential for trade creation if all the countries of the region are included. Also the signing of Free Trade Agreement of the South Asian countries would divert their trade with the non member countries. These results are based on the data that cover the period of SAPTA, so we can infer from these results that the evidence of trade creation under SAPTA promises well for SAFTA for India, Pakistan and Sri Lanka but it provides evidence of trade diversion for all members of SAFTA.

We conclude that SAFTA may not be beneficial in the short run but it would be beneficial in the long run. Further trade liberalisation process and movement toward industrialisation of region would minimise the trade diversion effect under SAFTA. Most important, the effective implementation of SAFTA is needed; SAFTA would require an encouraging economic and political environment and a strong willingness for integration 
and liberalisation of the SAARC member countries. South Asian countries should simplify and improve the tariff structure and procedure, easing foreign exchange controls, transit facilities for the landlocked countries, simplification of banking facilities for import financing. Also, transparent antidumping and countervailing duties in the region will be necessary for the confidence building between the SAARC members.

\section{APPENDIX 1}

Table 1

Macroeconomic Overview of the SAARC Countries

\begin{tabular}{lccccc}
\hline Countries & GDP & GDP & \multicolumn{3}{c}{ Trade $\%$} \\
\hline Bangladesh & 78992 & 6 & 520 & 84 & 146 \\
Bhutan & 1359 & 14 & 1900 & 39 & 132 \\
India & 1217490 & 7 & 1070 & 137 & 134 \\
Maldives & 1260 & 6 & 3630 & 37 & 95 \\
Nepal & 12615 & 5 & 400 & 37 & 144 \\
Pakistan & 168276 & 6 & 980 & 55 & 141 \\
Sri Lanka & 40714 & 6 & 1780 & 84 & 102 \\
\hline
\end{tabular}

Source: World Development Indicators 2009.

UNDP Human Development Report 2009.

\section{APPENDIX 2}

Estimates of Gravity Model with GLS

Cross-sectional Results for the Year 2006

\begin{tabular}{lcccc}
\hline \multirow{2}{*}{ Variables } & \multicolumn{4}{c}{2006} \\
\cline { 2 - 5 } Coefficient & T-statistics & Coefficient & T-statistic \\
\hline LOGGDP & $2.935^{*}$ & 2.151 & $4.826^{*}$ & 6.457 \\
LOGPCI & $0.529^{*}$ & 19.958 & $0.54^{*}$ & 20.381 \\
LOGDIST & $0.128^{*}$ & 3.724 & $0.145^{*}$ & 4.169 \\
LOGTARIFF & $-0.413^{*}$ & -5.126 & $-0.664^{*}$ & -8.213 \\
BORDER & $-0.041^{*}$ & 4.433 & $-0.026^{*}$ & 3.54 \\
SAFTA1 & $0.7^{*}$ & 2.853 & $0.769^{*}$ & 3.345 \\
SAFTA1N & $3.821^{*}$ & 3.190 & $2.159^{*}$ & 2.998 \\
SAFTA & $1.02^{*}$ & 4.547 & $1.052^{*}$ & 5.694 \\
SAFTAN & $-3.224^{*}$ & -3.175 & $-2.522^{*}$ & -9.194 \\
ECO & $-1.642^{*}$ & -7.51 & $-1.803^{*}$ & -10.935 \\
ASEAN1 & -0.344 & -0.678 & - & - \\
ASEAN2 & $0.511^{*}$ & 1.912 & - & - \\
NAFTA & $0.929^{*}$ & 1.998 & - & - \\
EC & 0.738 & 0.812 & - & - \\
$\mathrm{R}^{2}$ & 0.528 & 1.097 & - & - \\
D.W & 0.889 & - & - & - \\
\hline
\end{tabular}


Estimates of Gravity Model with GLS

Cross-sectional Results for the Year 2005

\begin{tabular}{lcccc}
\hline \multirow{2}{*}{ Variables } & \multicolumn{5}{c}{2005} & \\
\cline { 2 - 5 } Constant & $2.014^{* * *}$ & 2.501 & $5.746^{*}$ & 5.758 \\
LOGGDP & $0.610^{*}$ & 17.396 & $0.654^{*}$ & 19.580 \\
LOGPCI & $0.109^{*}$ & 2.712 & $0.037^{* *}$ & 0.947 \\
LOGDIST & $-0.329^{*}$ & -3.967 & $-0.712^{*}$ & -8.233 \\
LOGTARIFF & $-0.031^{*}$ & 4.698 & $-0.027^{*}$ & 3.67 \\
BORDER & $0 . .881^{* *}$ & 2.853 & $0.667^{*}$ & 2.289 \\
SAFTA1 & $2.181^{*}$ & 3.127 & $1.817^{*}$ & 2.279 \\
SAFTA1N & $1.331^{*}$ & 4.547 & $1.292^{*}$ & 5.925 \\
SAFTA & $-1.926^{* *}$ & -3.075 & $-2.778^{*}$ & -5.219 \\
SAFTAN & $-1.877^{*}$ & -6.289 & $-2.166^{*}$ & -9.684 \\
ECO & -0.356 & -0.525 & - & - \\
ASEAN1 & $1.194^{*}$ & 2.708 & - & - \\
ASEAN2 & 0.995 & 1.584 & - & - \\
NAFTA & 0.192 & 0.183 & - & - \\
EC & 0.303 & 0.927 & - & - \\
R $^{2}$ & 0.853 & - & - & - \\
D.W & 2.139 & - & - & - \\
\hline
\end{tabular}

Estimates of Gravity Model with GLS

Cross-sectional Results for the Year 2004

\begin{tabular}{lcccc}
\hline Variables & Coefficient & T-statistics & Coefficient & T-statistic \\
\hline Constant & $2.008^{* * *}$ & 1.661 & $5.746^{*}$ & 5.758 \\
LOGGDP & $0.640^{*}$ & 18.272 & $0.654^{*}$ & 19.580 \\
LOGPCI & $0.113^{*}$ & 2.774 & $0.037^{* *}$ & 0.947 \\
LOGDIST & $-0.437^{*}$ & -4.046 & $-0.712^{*}$ & -8.233 \\
BORDER & $0.832^{* *}$ & 2.853 & $0.667^{*}$ & 2.289 \\
SAFTA1 & $2.954^{*}$ & 3.127 & $1.817^{*}$ & 2.279 \\
SAFTA1N & $1.371^{*}$ & 4.547 & $1.292^{*}$ & 5.925 \\
SAFTA2 & $-1.926^{*}$ & -3.075 & $-2.778^{*}$ & -5.219 \\
SAFTA2N & $-1.877^{*}$ & -6.289 & $-2.166^{*}$ & -9.684 \\
ASEAN1 & $1.194^{*}$ & 2.708 & & \\
ASEAN2 & 0.995 & 1.584 & & \\
ECO & -0.356 & -0.525 & & \\
NAFTA & 0.192 & 0.183 & & \\
EC & 0.303 & 0.927 & & \\
$R^{2}$ & 0.853 & & & \\
D.W & 2.139 & & & \\
\hline
\end{tabular}


Estimates of Gravity Model with GLS

Cross-sectional Results for the Year 2003

\begin{tabular}{lcccc}
\hline Variables & Coefficient & T-statistics & Coefficient & T-statistics \\
\hline Constant & $2.317^{*}$ & 2.161 & 5.439 & 5.991 \\
LOGGDP & $0.603^{*}$ & 18.834 & $0.614^{*}$ & 19.847 \\
LOGPCI & $0.118^{*}$ & 3.261 & $0.073^{* *}$ & 2.021 \\
LOGDIST & $-0.429^{*}$ & -4.406 & $-0.696^{*}$ & -8.777 \\
BORDER & $0.788^{*}$ & 2.985 & $0.701^{*}$ & 2.641 \\
SAFTA1 & $3.243^{*}$ & 3.837 & $1.931^{*}$ & 2.710 \\
SAFTA1N & $1.254^{*}$ & 4.624 & $1.212^{*}$ & 6.163 \\
SAFTA2 & $-2.575^{*}$ & -4.742 & $-3.026^{*}$ & -6.544 \\
SAFTA2N & $-1.798^{*}$ & -6.696 & $-2.045^{*}$ & -10.101 \\
ASEAN1 & $0.966^{*}$ & 2.276 & & \\
ASEAN2 & $0.973^{*}$ & 1.722 & & \\
ECO & -0.352 & -0.576 & & \\
NAFTA & 0.374 & 0.395 & & \\
EC & 0.378 & 1.317 & & \\
R & 0.868 & & & \\
D.W & 2.175 & & & \\
\hline
\end{tabular}

\section{REFERENCES}

Akram, Waheed (2008) Pakistan Exports's Potentials: A Gravity Model Analysis. State Bank of Pakistan. (Working Paper No. 23).

Anderson J. and E. Van Wincoop (2003) Gravity with Gravitas: A solution to the Border Puzzle. The American Economic Review 93,170-192.

Anderson, J. E. (1979) A Theoretical Foundation for the Gravity Equation. The American Economic Review 69:1, 106-116.

Bergstarnd, J. H. (1985) The Gravity Equation in International Trade: Some Microeconomic Foundations and Empirical Evidence. Review of Economics and Statistics 67:3, 474-81.

Bergstarnd, J. H. (1989) The Generalised Gravity Equation, Monopolistic Competition, and the Factor-Proportions Theory in International Trade. Review of Economics and Statistics 71:1, 143-53.

Bergstarnd, J. H. (1990) The Heckscher-Ohlin-Samuelson Model, the Linder Hypothesis, and the Determinants of Bilateral Intra-industry Trade. Economic Journal 100:4, $1216-1229$.

Bhatachariya (2004) Does Bangladesh Fits from Prefential Trade with India: A Gravity Analysis. Economic and Political Weekly 39: 38.

Blanchard, O. J. (1967) Comment. Journal of Business and Economic Statistics 5, 449451.

Frankel and Romer (1999) Does Trade Cause Growth? The American Economic Review 89:3, 379-399.

Gujrati, D. N. (1988) Basic Econometrics (Second Edition). New York: McGraw-Hill.

Hassan, M. K. (2001) Is SAARC a Viable Economic Block? Evidence from Gravity Model. Journal of Asian Economics 2:2, 263-290. 
Helpman, Melitz and Rubinstain (2006) Trading Partners and Trading Volumes. National Bureau of Economic Research. (Working Paper No. 129277).

International Monetary Fund (2003 -2006) Direction of Trade Statistics.

Judge, G. G., R. C. Hill, W. Griffiths, W. H. Lutkepohl, and T. C. Lee (1988) Introduction to the Theory and Practice of Econometrics (Second Edition). New York: John Wiley and Sons.

Linnemann, Hans (1966) An Econometrrc Stud, of Ir rernur onuTlr udeFlows. Amsterdam: North-Holland Publishing Co.

Panagariya, A. (1996) The Free Trade Area of the Americas: Good for Latin America? The World Economy 19:5, 485-516.

Prewo, Wilfried (1978) Determinants of the Trade Pattern among OECD Countries from 1958 to 1974. Jahrhucher fur Nur onulehonom eu rld Stut strh 193, 341-358.

Rahman (2004) Trade Potential in SAFTA: An Application of Augmented Gravity Model, Centre for Policy Dialogue (CPD). (Paper No. 61).

Reihan and Razzaque (2007) Welfare Effects of South Asia Free Trade Area. Study prepared for UNCTAD Regional Centre Colombo.

Tinbergen, Jan (1962) Shaping the World Economy: Suggestions for an International Economic Policy. New York: The Twentieth Century Fund.

UNCTAD United Nations Statistics Division (2004) UN Commodity Trade Statistics Database (UN Comtrade). Available at http://unstats.un.org/unsd/comtrade/, accessed May 13. 